\title{
Implementasi Moora Berbasis Web pada Penentuan Kelayakan Penerima Bantuan Siswa Miskin
}

\author{
Aron Saputra Sirait $1^{1^{*}}$, M. Safii ${ }^{2}$, Indra Gunawan ${ }^{3}$ \\ ${ }^{1,3}$ Program Studi Teknik Informatika, STIKOM Tunas Bangsa, Pematangsiantar \\ ${ }^{2}$ Program Studi Komputerisasi Akuntansi, AMIK Tunas Bangsa, Pematangsiantar \\ Email: ${ }^{1 *}$ aron13sirait@gmail.com
}

\begin{abstract}
The Poor Student Assistance Program (BSM) is an aid from the government with the aim that poor children who excel are able to continue schooling. So that in order to minimize this assistance can be channeled properly on target, it is necessary to conduct a fairly strict selection based on the criteria that have been set. This study proposes the use of the website-based Moora method to overcome this problem. The MOORA method is very simple, stable, and powerful, even this method does not require an expert in mathematics to use it and does not require complicated mathematical calculations. The BSM assistance that will be discussed in this research is $S D$ NEGERI 127696 Pematangsiantar City using 7 criteria, namely: Parent's Occupation, Income, Number of Dependents, Attendance, Last Semester Grades, Academic Achievement and Personality. The sample data used were 18 students. This study resulted in the highest value alternative on behalf of Ade Putri Mekaria Laila with an Optimization value of 2.22692. So it can be concluded that the Moora method can be used as a decision support method in the selection of BSM recipients.
\end{abstract}

Keywords: DSS, Moora, Poor Students, Minimum Calculation, Multi-objective System.

\begin{abstract}
ABSTRAK
Program Bantuan Siswa Miskin (BSM) merupakan bantuan dari pemerintah dengan tujuan agar anak-anak miskin yang berprestasi mampu terus sekolah. Sehingga untuk meminimalisir agar bantuan ini dapat disalurkan dengan tepat sasaran, maka perlu dilakukan seleksi yang cukup ketat dengan berdasarkan kriteria kriteria yang telah ditetapkan. Penelitian ini mengusulkan penggunaan metode Moora berbasis website untuk mengatasi masalah tersebut. Metode MOORA sangat sederhana, stabil, dan kuat, bahkan metode ini tidak membutuhkan seorang ahli di bidang matematika untuk menggunakan nya serta tidak membutuhkan perhitungan matematis yang rumit. Bantuan BSM yang akan dibahas pada penelitian ini adalah SD NEGERI 127696 Kota Pematangsiantar dengan menggunakan 7 kriteria, yakni : Pekerjaan Orang Tua, Penghasilan, Jumlah Tanggungan, Kehadiran, Nilai Semester Terakhir, Prestasi Akademik dan Kepribadian. Sampel data yang digunakan sebanyak 18 siswa. Penelitian ini menghasilkan alternatif nilai tertinggi atas nama Ade Putri Mekaria Laila dengan nilai Optimasi 2,22692. Sehingga dapat disimpulkan bahwa metode Moora dapat digunakan sebagai metode pendukung keputusan pada seleksi penerima BSM.
\end{abstract}

Kata Kunci: SPK, Moora, Siswa Miskin, Perhitungan Minimum, Multiobjektif Sistem

\section{Pendahuluan}

Program BSM merupakan Program Nasional yang bertujuan untuk menghilangkan halangan siswa miskin berpartisipasi untuk bersekolah dengan membantu siswa miskin memperoleh akses pelayanan pendidikan yang layak, mencegah putus sekolah, menarik siswa miskin untuk kembali bersekolah, membantu siswa memenuhi kebutuhan dalam kegiatan pembelajaran, mendukung program Wajib Belajar Pendidikan Dasar
Sembilan Tahun (bahkan hingga tingkat menengah atas), serta membantu kelancaran program sekolah [1]. Melalui Program BSM ini diharapkan anak usia sekolah dari rumah-tangga/keluarga miskin dapat terus bersekolah, tidak putus sekolah, dan di masa depan diharapkan mereka dapat memutus rantai kemiskinan yang saat ini dialami orangtuanya. Program BSM juga mendukung komitmen pemerintah untuk meningkatkan angka partisipasi pendidikan di Kabupaten/Kota miskin dan terpencil serta pada kelompok marjinal [2]. Banyak

Diterima Redaksi: 03-09-2021 | Selesai Revisi: 04-09-2021 | Diterbitkan Online: 10-09-2021 
sekolah-sekolah di Indonesia yang memperoleh Bidikmisi pada Institut Teknologi dan Bisnis STIKOM bantuan BSM ini, salah satunya adalah SD NEGERI Bali menggunakan metode Moora. Hasil 127696 yang terletak Jl. Kol No.36 Kelurahan Kebun pemeringkatan menunjukkan bahwa ranking Sayur Kecamatan Siantar Timur Kota Pematangsiantar. berdasarkan potensi akademik yang diperoleh dari

Penentuan siswa penerima bantuan atau beasiswa pada SD Negeri 127696 selama ini dilakukan secara catatan manual dan untuk pelaporan masih menggunakan aplikasi berbasis spreadsheet (Ms. Excel) yang belum memiliki basis data sehingga kemungkinan terjadi inkonsistensi data. Penilaian yang diberikan oleh pengambil keputusan masih menggunakan prediksi atau perkiraan. Sehingga dikhawatirkan dapat menimbulkan penilaian secara subjektif seperti kepentingan pribadi. Berdasarkan permasalahan tersebut diperlukan sistem pendukung keputusan yang dapat memberikan salah satu solusi untuk mengatasi kekhawatiran yang ditimbulkan. Akan tetapi banyak nya metode Sistem Pendukung Keputusan seperti AHP Hal-hal terkait tersebut yang melatar belakangi [3]-[6], Moora [7]-[9], Electre [10]-[17], Maut [18]- dilakukannya penelitian ini dengan menggunakan [20], Promethee [21]-[24], PSI [25]-[27] Topsis [28]- metode Moora berbasis Website, karena Metode [30], Vikor [31]-[33], dan banyak lagi lainnya yang MOORA sangat sederhana, stabil, dan kuat, bahkan menimbulkan kebingungan tersendiri bagi pengambil metode ini tidak membutuhkan seorang ahli di bidang kebijakan (Kepala Sekolah) di sekolah tersebut. matematika untuk menggunakan nya serta tidak Sehingga pada makalah ini diusulkan penggunaan membutuhkan.

Sistem Pendukung Keputusan dengan metode Moora.

Beberapa penelitian terdahulu tentang pengambilan keputusan menggunakan metode Moora diantaranya: Penelitian untuk menentukan lokasi industri berbasis spasial menggunakan metode MOORA. Berdasarkan hasil pengujian perhitungan manual dengan output sistem memiliki nilai MSE sebesar 0,0000054. Sedangkan nilai validasi menggunakan korelasi Spearman Rank sebesar 0,9. Hal ini menunjukan bahwa metode MOORA dapat menentukan lokasi industri menggunakan data berbasis spasial dengan nilai korelasi yang mendekati nilai 1 [7]. Berikutnya penelitian yang dilakukan untuk Seleksi Beasiswa

\section{Metode Penelitian}

\subsection{Lokasi dan Waktu Penelitian}

Penelitian dilakukan pada SD Negeri 127868 Kota Pematangsiantar pada tanggal 20 Juni 2020 s/d 27 Juni 2020. Wawancara untuk pengumpulan data dilakukan kepada pihak pengambil keputusan (Kepala Sekolah) untuk mendapatkan data yang akan diolah, yakni data siswa yang akan diseleksi sebagai penerima BSM pada sekolah tersebut. Ada 18 data siswa yang akan menjadi alternatif.

Tabel 1. Data Penelitian

\begin{tabular}{|c|c|c|c|c|c|c|c|c|}
\hline \multirow[b]{2}{*}{ No } & \multirow[b]{2}{*}{ Alternatif } & \multicolumn{7}{|c|}{ Kriteria } \\
\hline & & Pekerjaan Ortu & $\begin{array}{c}\text { Peng } \\
\text { hasilan }\end{array}$ & $\begin{array}{c}\text { Tang } \\
\text { gungan }\end{array}$ & $\begin{array}{l}\text { Keha } \\
\text { diran }\end{array}$ & $\begin{array}{c}\text { Nilai } \\
\text { Semester }\end{array}$ & $\begin{array}{c}\text { Prestasi } \\
\text { Akademik }\end{array}$ & Kepribadian \\
\hline 1 & Ade Putri Mekaria Laila & Bertenun & 1.000 .000 & 5 & 100 & 95 & 3 & 90 \\
\hline 2 & Juanda Vernis Siahaan & Wiraswasta & 1.300 .000 & 5 & 96 & 95 & 0 & 80 \\
\hline 3 & Juniver Panca Wibawa & Wiraswasta & 3.000 .000 & 5 & 90 & 80 & 1 & 87 \\
\hline 4 & Muhammad Reyhan & Pedagang & 1.100 .000 & 3 & 100 & 89 & 2 & 86 \\
\hline 5 & Paulus Juninho Manik & Supir & 1.000 .000 & 3 & 100 & 93 & 1 & 88 \\
\hline 6 & Rahel Sapetra Sihombing & Wiraswasta & 1.000 .000 & 3 & 96 & 91 & 1 & 86 \\
\hline 7 & Randika Aditya Bastion Purba & Wiraswasta & 900.000 & 2 & 97 & 89 & 0 & 85 \\
\hline 8 & Reynardo Sidabutar & Ojek Online & 1.000 .000 & 4 & 98 & 89 & 1 & 81 \\
\hline 9 & Samuel Valentino & Supir & 900.000 & 2 & 94 & 80 & 2 & 88 \\
\hline 10 & Wisler Siregar & Pedagang & 1.300 .000 & 3 & 95 & 85 & 1 & 86 \\
\hline 11 & Agusto Marpaung & PNS & 1.000 .000 & 4 & 90 & 96 & 1 & 87 \\
\hline 12 & Andre Wijaya & Wiraswasta & 1.200 .000 & 1 & 97 & 96 & 2 & 84 \\
\hline 13 & Angelita Sidauruk & Wiraswasta & 1.300 .000 & 3 & 98 & 95 & 1 & 86 \\
\hline 14 & Boas Uluan Sibarani & Wiraswasta & 1.100 .000 & 5 & 95 & 93 & 1 & 85 \\
\hline 15 & Chirta Aulia Sibarani & Buruh & 1.000 .000 & 4 & 100 & 91 & 0 & 86 \\
\hline 16 & Eldana Marina Hasibuan & Wiraswasta & 2.000 .000 & 1 & 95 & 94 & 1 & 85 \\
\hline 17 & Hariman Loeis Pramata Bukit & Petani & 1.300 .000 & 2 & 80 & 92 & 2 & 90 \\
\hline 18 & Imrod Pangeran Sinaga & Tukang & 1.100 .000 & 4 & 95 & 80 & 1 & 82 \\
\hline
\end{tabular}

DOI: $\mathrm{xxxx}$

Lisensi: Creative Commons Attribution 4.0 International (CC BY 4.0) 
Berdasarkan Tabel 1 dapat dilihat bahwa nilai pada Kriteria Pekerjaan Orang Tua menggunakan data non numerik. Untuk mendapatkan hasil yang baik, diberikan nilai linker 1 s/d 5 dengan berdasarkan parameter berikut: 1. PNS - TNI - Polri, 2. Wiraswasta - Wirausaha, 3. Petani - Pedagang, 4. Buruh - Tukang, 5. Ojek - Supir.

\subsection{Tahapan Penelitian}

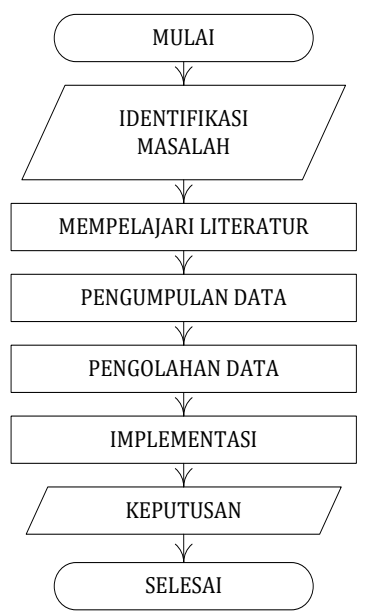

Gambar 1. Tahapan Penelitian

a. Identifikasi Masalah

Mengidentifikasi masalah yang terkait dalam menentukan pestisida terbaik untuk perawatan tanaman cabai dengan menentukan kriteria dan alternatif.

b. Mempelajari Literatur

Penelitian ini dilandasi rujukan atau referensi yang terkait guna mendapatkan informasi pendukung dalam penelitian.

c. Pengumpulan Data

Pengumpulan data dilakukan dengan melakukan teknik di SD Negeri 127868 Kota Pematangsiantar pada tanggal 20 Juni 2020 s/d 27 Juni 2020.

d. Pengolahan Data

Proses yang dilakukan untuk menentukan siswa yang layak mendapatkan BSM menggunakan kriteria, sub kriteria dan alternatif yang digunakan.

e. Implementasi

Penulis melakukan Implementasi dengan menggunakan sistem Website Algoritma Moora untuk menentukan siswa yang layak mendapatkan BSM di SD Negeri 127696 Kota Pematangsiantar.

f. Keputusan

Hasil yang diberikan oleh sistem dan analisa penulis dapat memberikan solusi berupa rekomendasi kepada pihak pengambil keputusan untuk mendapatkan rekomendasi siswa yang layak mendapatkan BSM di SD Negeri 127696 Kota Pematangsiantar.

\subsection{Pengumpulan Data}

Pengumpulan data yang digunakan untuk penelitian terdapat beberapa prosedur yang digunakan, yaitu terdiri dari :

1. Studi Kepustakaan (Libarry Research)

Memanfaatkan perpustakaan, buku, prosiding atau jurnal sebagai referensi dalam menentukan faktor, parameter, dan label yang digunakan untuk penelitian.

2. Penelitian Lapangan (Field Work Research)

Penelitian yang dilakukan secara langsung dengan menggunakan teknik Studi Literatur, Penulis memperoleh informasi dengan mengumpulkan data, mempelajari data, validasi data dan mencari referensi terkait dengan kasus pada penelitian. Luaran dari studi literatur ini adalah tersusun dan terkoleksinya referensi yang baik dan benar dengan penelitian.

\section{Hasil dan Pembahasan}

\subsection{Analisis Data}

Data kriteria dan bobot yang digunakan dalam Penentuan Kelayakan Penerima Bantuan Siswa Miskin dapat dilihat pada tabel 1.

Tabel 2. Data Kriteria dan Bobot

\begin{tabular}{cclcc}
\hline No & & \multicolumn{1}{c}{ Kriteria } & Tipe & Bobot \\
\hline 1 & C1 & Pekerjaan Orang Tua & Benefit & 1,8 \\
2 & C2 & Penghasilan Orang Tua & Cost & 1,7 \\
3 & C3 & Jumlah Tanggungan & Cost & 1,4 \\
4 & C4 & Kehadiran & Benefit & 1,5 \\
5 & C5 & Nilai Semester & Benefit & 0,8 \\
6 & C6 & Prestasi Akademik & Benefit & 1,8 \\
7 & C7 & Kepribadian & Benefit & 1 \\
\hline
\end{tabular}

Tabel 3. Data yang Sudah Diolah (Matriks Keputusan)

\begin{tabular}{|c|c|c|c|c|c|c|c|c|}
\hline \multirow{2}{*}{ No } & \multirow{2}{*}{ Alternatif } & \multicolumn{7}{|c|}{ Kriteria } \\
\hline & & C1 & $\mathbf{C 2}$ & C3 & C4 & $\mathbf{C 5}$ & C6 & C7 \\
\hline 1 & Ade Putri Mekaria Laila & 2 & 1.000 .000 & 5 & 100 & 95 & 3 & 90 \\
\hline 2 & Juanda Vernis Siahaan & 2 & 1.300 .000 & 5 & 96 & 95 & 0 & 80 \\
\hline 3 & Juniver Panca Wibawa & 2 & 3.000 .000 & 5 & 90 & 80 & 1 & 87 \\
\hline 4 & Muhammad Reyhan & 3 & 1.100 .000 & 3 & 100 & 89 & 2 & 86 \\
\hline 5 & Paulus Juninho Manik & 5 & 1.000 .000 & 3 & 100 & 93 & 1 & 88 \\
\hline 6 & Rahel Sapetra Sihombing & 2 & 1.000 .000 & 3 & 96 & 91 & 1 & 86 \\
\hline 7 & Randika Aditya Bastion Purba & 2 & 900.000 & 2 & 97 & 89 & 0 & 85 \\
\hline 8 & Reynardo Sidabutar & 5 & 1.000 .000 & 4 & 98 & 89 & 1 & 81 \\
\hline 9 & Samuel Valentino & 5 & 900.000 & 2 & 94 & 80 & 2 & 88 \\
\hline 10 & Wisler Siregar & 2 & 1.300 .000 & 3 & 95 & 85 & 1 & 86 \\
\hline
\end{tabular}

DOI: $\mathrm{xxxx}$

Lisensi: Creative Commons Attribution 4.0 International (CC BY 4.0) 


\begin{tabular}{|c|c|c|c|c|c|c|c|c|}
\hline \multirow{2}{*}{ No } & \multirow{2}{*}{ Alternatif } & \multicolumn{7}{|c|}{ Kriteria } \\
\hline & & C1 & $\mathbf{C 2}$ & C3 & C4 & $\mathrm{C5}$ & C6 & C7 \\
\hline 11 & Agusto Marpaung & 1 & 1.000 .000 & 4 & 90 & 96 & 1 & 87 \\
\hline 12 & Andre Wijaya & 2 & 1.200 .000 & 1 & 97 & 96 & 2 & 84 \\
\hline 13 & Angelita Sidauruk & 2 & 1.300 .000 & 3 & 98 & 95 & 1 & 86 \\
\hline 14 & Boas Uluan Sibarani & 2 & 1.100 .000 & 5 & 95 & 93 & 1 & 85 \\
\hline 15 & Chirta Aulia Sibarani & 4 & 1.000 .000 & 4 & 100 & 91 & 0 & 86 \\
\hline 16 & Eldana Marina Hasibuan & 2 & 2.000 .000 & 1 & 95 & 94 & 1 & 85 \\
\hline 17 & Hariman Loeis Pramata Bukit & 3 & 1.300 .000 & 2 & 80 & 92 & 2 & 90 \\
\hline 18 & Imrod Pangeran Sinaga & 4 & 1.100 .000 & 4 & 95 & 80 & 1 & 82 \\
\hline
\end{tabular}

Selanjutnya membuat normalisasi dari matriks $X_{11}=$

keputusan dengan menggunakan rumus berikut :

$$
X *_{i j}=\frac{x_{i j}}{\sqrt{\left[\sum_{j-1}^{m} x_{i j}^{2}\right]}}
$$

Maka diperoleh :

$$
\begin{gathered}
2 / \sqrt{\left(2^{2}+3^{2}+1^{2}+2^{2}+2^{2}+2^{2}+4^{2}+2^{2}+3^{2}\right.} \\
+2^{2}+2^{2}+2^{2}+3^{2}+2^{2}+2^{2}+2^{2}+2^{2}+2^{2} \\
\quad=0,2041
\end{gathered}
$$

Begitu seterusnya hingga selesai, hingga memperoleh nilai normalisasi seperti pada tabel 4 berikut.

\begin{tabular}{|c|c|c|c|c|c|c|c|c|}
\hline \multirow{2}{*}{ No } & \multirow{2}{*}{ Alternatif } & \multicolumn{7}{|c|}{ Kriteria } \\
\hline & & C1 & $\mathrm{C2}$ & $\mathbf{C 3}$ & $\mathrm{C4}$ & C5 & C6 & C7 \\
\hline 1 & Ade Putri Mekaria Laila & 2 & 1.000 .000 & 5 & 100 & 95 & 3 & 90 \\
\hline 2 & Juanda Vernis Siahaan & 2 & 1.300 .000 & 5 & 96 & 95 & 0 & 80 \\
\hline 3 & Juniver Panca Wibawa & 2 & 3.000 .000 & 5 & 90 & 80 & 1 & 87 \\
\hline 4 & Muhammad Reyhan & 3 & 1.100 .000 & 3 & 100 & 89 & 2 & 86 \\
\hline 5 & Paulus Juninho Manik & 5 & 1.000 .000 & 3 & 100 & 93 & 1 & 88 \\
\hline 6 & Rahel Sapetra Sihombing & 2 & 1.000 .000 & 3 & 96 & 91 & 1 & 86 \\
\hline 7 & Randika Aditya Bastion Purba & 2 & 900.000 & 2 & 97 & 89 & 0 & 85 \\
\hline 8 & Reynardo Sidabutar & 5 & 1.000 .000 & 4 & 98 & 89 & 1 & 81 \\
\hline 9 & Samuel Valentino & 5 & 900.000 & 2 & 94 & 80 & 2 & 88 \\
\hline 10 & Wisler Siregar & 2 & 1.300 .000 & 3 & 95 & 85 & 1 & 86 \\
\hline 11 & Agusto Marpaung & 1 & 1.000 .000 & 4 & 90 & 96 & 1 & 87 \\
\hline 12 & Andre Wijaya & 2 & 1.200 .000 & 1 & 97 & 96 & 2 & 84 \\
\hline 13 & Angelita Sidauruk & 2 & 1.300 .000 & 3 & 98 & 95 & 1 & 86 \\
\hline 14 & Boas Uluan Sibarani & 2 & 1.100 .000 & 5 & 95 & 93 & 1 & 85 \\
\hline 15 & Chirta Aulia Sibarani & 4 & 1.000 .000 & 4 & 100 & 91 & 0 & 86 \\
\hline 16 & Eldana Marina Hasibuan & 2 & 2.000 .000 & 1 & 95 & 94 & 1 & 85 \\
\hline 17 & Hariman Loeis Pramata Bukit & 3 & 1.300 .000 & 2 & 80 & 92 & 2 & 90 \\
\hline 18 & Imrod Pangeran Sinaga & 4 & 1.100 .000 & 4 & 95 & 80 & 1 & 82 \\
\hline
\end{tabular}

Tabel 3. Data yang Sudah Diolah (Matriks Keputusan)

\begin{tabular}{|c|c|c|c|c|c|c|c|c|}
\hline \multirow{2}{*}{ No } & \multirow{2}{*}{ Alternatif } & \multicolumn{7}{|c|}{ Kriteria } \\
\hline & & C1 & $\mathbf{C 2}$ & $\mathbf{C 3}$ & $\mathbf{C 4}$ & C5 & C6 & C7 \\
\hline 1 & Ade Putri Mekaria Laila & 0,2041 & 0,1755 & 0,3348 & 0,2461 & 0,2479 & 0,5071 & 0,2513 \\
\hline 2 & Juanda Vernis Siahaan & 0,3062 & 0,2282 & 0,3348 & 0,2363 & 0,2479 & 0,0000 & 0,2513 \\
\hline 3 & Juniver Panca Wibawa & 0,1021 & 0,5266 & 0,3348 & 0,2363 & 0,2088 & 0,1690 & 0,2513 \\
\hline 4 & Muhammad Reyhan Al-Fachrizi Lubis & 0,2041 & 0,1931 & 0,2009 & 0,2461 & 0,2322 & 0,3381 & 0,2513 \\
\hline 5 & Paulus Juninho Manik & 0,2041 & 0,1755 & 0,2009 & 0,2461 & 0,2427 & 0,1690 & 0,2010 \\
\hline 6 & Rahel Sapetra Sihombing & 0,2041 & 0,1755 & 0,2009 & 0,2363 & 0,2375 & 0,1690 & 0,2513 \\
\hline 7 & Randika Aditya Bastion Purba & 0,4082 & 0,1580 & 0,1339 & 0,2387 & 0,2322 & 0,0000 & 0,2010 \\
\hline 8 & Reynardo Sidabutar & 0,2041 & 0,1755 & 0,2679 & 0,2412 & 0,2322 & 0,1690 & 0,2513 \\
\hline 9 & Samuel Valentino & 0,3062 & 0,1580 & 0,1339 & 0,2313 & 0,2088 & 0,3381 & 0,2010 \\
\hline 10 & Wisler Siregar & 0,2041 & 0,2282 & 0,2009 & 0,2338 & 0,2218 & 0,1690 & 0,2513 \\
\hline 11 & Agusto Marpaung & 0,2041 & 0,1755 & 0,2679 & 0,2215 & 0,2505 & 0,1690 & 0,2513 \\
\hline 12 & Andre Wijaya & 0,2041 & 0,2107 & 0,0670 & 0,2387 & 0,2505 & 0,3381 & 0,2513 \\
\hline 13 & Angelita Sidauruk & 0,3062 & 0,2282 & 0,2009 & 0,2412 & 0,2479 & 0,1690 & 0,2010 \\
\hline 14 & Boas Uluan Sibarani & 0,2041 & 0,1931 & 0,3348 & 0,2338 & 0,2427 & 0,1690 & 0,2010 \\
\hline 15 & Chirta Aulia Sibarani & 0,2041 & 0,1755 & 0,2679 & 0,2461 & 0,2375 & 0,0000 & 0,2513 \\
\hline 16 & Eldana Marina Hasibuan & 0,2041 & 0,3511 & 0,0670 & 0,2338 & 0,2453 & 0,1690 & 0,2010 \\
\hline 17 & Hariman Loeis Pramata Bukit & 0,2041 & 0,2282 & 0,1339 & 0,1969 & 0,2401 & 0,3381 & 0,2513 \\
\hline 18 & Imrod Pangeran Sinaga & 0,2041 & 0,1931 & 0,2679 & 0,2338 & 0,2088 & 0,1690 & 0,2513 \\
\hline
\end{tabular}

Tabel 4. Hasil Normalisasi

Selanjutnya mencari nilai optimasi dari setiap alternatif Maka diperoleh :

dengan ketentuan bobot pada kriteria yang digunakan $\mathrm{y}_{1}=(0,2041 * 1,8)+\left(0,1755^{*} 1,7 *(-1)\right)+(0,3348 * 1,4 *(-$ dengan menggunakan rumus sebagai berikut :

$$
y_{i}=\sum_{j=1}^{g} w_{j} x *_{i j}-\sum_{j=g+1}^{g} w_{j} x *_{i j}
$$$$
1))+(0,2469 * 1,5)+(0,2479 * 0,8)+(0,5071 * 1,8)+
$$$$
(0,2513 * 1)
$$$$
=1,3317
$$

DOI: $\mathrm{xxxx}$

Lisensi: Creative Commons Attribution 4.0 International (CC BY 4.0) 
Begitu seterusnya hingga $\mathrm{y}_{18}$. Sehingga memperoleh nilai optimasi keseluruhan seperti pada tabel 5.

Tabel 5. Hasil Optimasi

\begin{tabular}{clc}
\hline No & \multicolumn{1}{c}{ Nama } & Nilai Optimasi \\
\hline 1 & Ade Putri Mekaria Laila & 1,3317 \\
2 & Juanda Vernis Siahaan & 0,4984 \\
3 & Juniver Panca Wibawa & $-0,1034$ \\
4 & Muhammad Reyhan Lubis & 1,1726 \\
5 & Paulus Juninho Manik & 0,8563 \\
6 & Rahel Sapetra Sihombing & 0,8876 \\
7 & Randika Aditya Bastion Purba & 1,0236 \\
8 & Reynardo Sidabutar & 0,7971 \\
9 & Samuel Valentino & 1,4186 \\
10 & Wisler Siregar & 0,7819 \\
11 & Agusto Marpaung & 0,7822 \\
12 & Andre Wijaya & 1,3338 \\
13 & Angelita Sidauruk & 0,9473 \\
14 & Boas Uluan Sibarani & 0,6205 \\
15 & Chirta Aulia Sibarani & 0,5044 \\
16 & Eldana Marina Hasibuan & 0,7290 \\
17 & Hariman Loeis Pramata Bukit & 1,1391 \\
18 & Imrod Pangeran Sinaga & 0,7374 \\
\hline
\end{tabular}

Setelah mendapatkan nilai Optimasi keseluruh alternatif, langkah terakhir mencari nilai perankingan yang diambil dari nilai Optimasi pada tabel 5. Adapun hasil optimasi yang dirankingkan dapat dilihat pada tabel 6 .

Tabel 6. Hasil Ranking

\begin{tabular}{cll}
\hline Ranking & \multicolumn{1}{c}{ Alternatif } & Nilai Optimasi \\
\hline 1 & Ade Putri Mekaria Laila & 2.2692 \\
2 & Samuel Valentino & 1.7935 \\
3 & Muhammad Reyhan & 1.7351 \\
4 & Boas Uluan Sibarani & 1.5580 \\
5 & Angelita Sidauruk & 1.5470 \\
6 & Reynardo Sidabutar & 1.5321 \\
7 & Andre Wijaya & 1.5213 \\
8 & Agusto Marpaung & 1.5141 \\
9 & Hariman Loeis Pramata Bukit & 1.5097 \\
10 & Randika Aditya Bastion Purba & 1.4873 \\
11 & Imrod Pangeran Sinaga & 1.4501 \\
12 & Paulus Juninho Manik & 1.4358 \\
13 & Rahel Sepetra Sihombing & 1.4188 \\
14 & Juanda Vernis Siahaan & 1.3986 \\
15 & Wisler Siregar & 1.3443 \\
16 & Chirta Aulia Sibarani & 1.2543 \\
17 & Eldana Marina Hasibuan & 0.9165 \\
18 & Juniver Panca Wibawa & 0.8340 \\
\hline
\end{tabular}

Tabel 6 menjelaskan hasil yang diperoleh dengan nilai tertinggi diperoleh Ade Putri Mekaria Laila dengan nilai Optimasi 2,22692, tertinggi kedua diperoleh Samuel Valentino dengan nilai Optimasi 1,7935, dan tertinggi ketiga dipeorleh Muhammad Reyhan Al Fahrizi Lubis dengan nilai 1,7351.

\subsection{Implementasi}

Bagian Implementasi ini berisikan tampilan sistem metode Moora berbasis web menggunakan aplikasi Dreamweaver dan database MySQL untuk menentukan Kelayakan Penerima Bantuan Siswa Miskin (BSM) pada SD NEGERI 127696.

1. Menu Utama

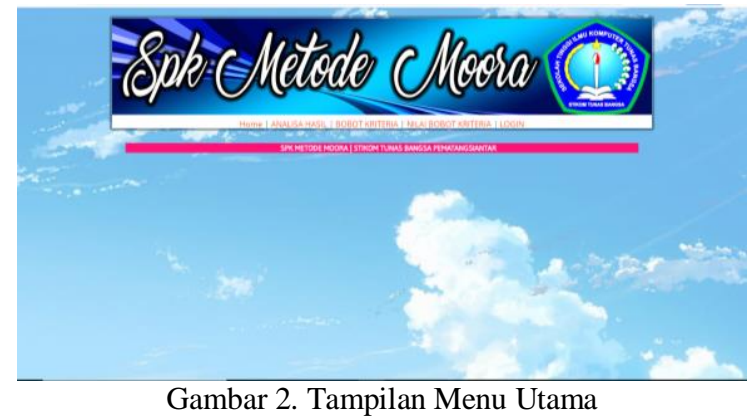

Gambar 2 merupakan tampilan utama sistem metode Moora untuk menentukan kelayakan penerima Bantuan Siswa Miskin (BSM) pada SD Negeri 127696 yang terdiri dari sub menu Analisa Hasil untuk melihat hasil pengolahan data, sub menu Bobot Kriteria untuk memvalidasi kriteria yang akan digunakan, sub menu Nilai Bobot Kriteria untuk menilai bobot kriteria yang digunakan dan sub menu Login untuk autentifikasi admin dalam menginput data kriteria dan data alternatif.

2. Form Kriteria dan Bobot Kriteria

Form kriteria dan bobot kriteria digunakan untuk menentukan kriteria dan bobot kriteria yang digunakan. Kriteria dan nilai Bobot Kriteria diinput melalui form input kriteria yang dapat dilihat pada gambar 3.

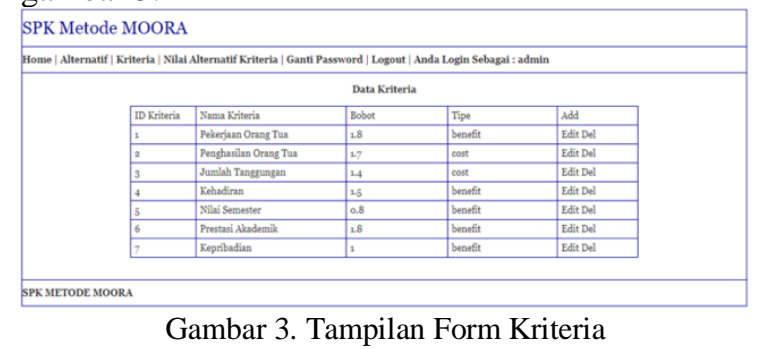

Proses input kriteria dapat mengklik tombol Add pada sistem sehingga menampilkan Form Tambah Data Kriteria seperti gambar 4.

\begin{tabular}{|l|l|}
\hline \multicolumn{2}{|c|}{ Tambah Data Kriteria } \\
\hline ID Kriteria & \\
\hline Nama Kriteria & \\
\hline Bobot & \\
\hline Tipe & \multicolumn{1}{c|}{ } \\
\hline & Simpan \\
\hline
\end{tabular}

Gambar 4. Tampilan Form Input Kriteria

Setelah input Kriteria, Bobot dan Tipe yang ditentukan, hasil kriteria yang telah diinput dapat dilihat pada gambar 5 . 


\begin{tabular}{|l|l|}
\hline \multicolumn{2}{|c|}{ BOBOT KRITERIA } \\
\hline Pekerjaan Orang Tua (benefit) & 1.8 \\
\hline Penghasilan Orang Tua (cost) & 1.7 \\
\hline Jumlah Tanggungan (cost) & 1.4 \\
\hline Kehadiran (benefit) & 1.5 \\
\hline Nilai Semester (benefit) & 0.8 \\
\hline Prestasi Akademik (benefit) & 1.8 \\
\hline Kepribadian (benefit) & 1 \\
\hline
\end{tabular}

Gambar 5. Tampilan dari Sub Menu Data Kriteria

\section{Form Alternatif}

Form alternatif digunakan untuk menentukan dan memvalidasi alternatif calon penerima BSM di SD NEGERI 127696. Alternatif diinput pada form input Alternatif yang dapat dilihat pada gambar 6.

\section{SPK Metode MOORA}

\begin{tabular}{|c|c|c|c|}
\hline \multicolumn{4}{|c|}{ 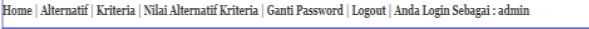 } \\
\hline \multicolumn{4}{|c|}{ Data Altermatif } \\
\hline D. Alteranaif & Nama Alltemantif Produls & Deskitipi & Add \\
\hline An & Ade Putiti Nekaraia Lalla & & Eatit Del \\
\hline Ato & Juanda Venilis Silhan & & Ealit Del \\
\hline All & Juniver Pance Vibarana & & Eadit Del \\
\hline A12 & $\begin{array}{l}\text { Mulhammed Reghan Al Fachiliz } \\
\text { Luntis }\end{array}$ & & EDait Del \\
\hline Als & 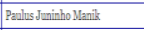 & & Eajit Del \\
\hline A4 & Rakele Speptas Shorbing & & Eain Del \\
\hline A15 & Randila Adityga Bastion Purba & & Eajit Del \\
\hline A16 & Regyardo 5idabutar & & Eajit Del \\
\hline$A_{A 7}$ & Sesmel Vilakentino & & Eajit Del \\
\hline$A+8$ & Wilier Sireggr & & Eadit Del \\
\hline A2 & Agrsto Mapang & & Eajit Del \\
\hline As & Andre Wijays & & Eajit Del \\
\hline A4 & Angelita sidarndk & & Eajit Del \\
\hline $\mathrm{A}_{5}$ & Boas Than Sharani & & Eäitpel \\
\hline A6 & Chitratilis Sharani & & Eitit Del \\
\hline A7 & Eldena: Narina Hasbban & & EäitDel \\
\hline$A B$ & $\begin{array}{l}\text { Hariman Lovis Pramatata Biliti } \\
\end{array}$ & & Eajit Del \\
\hline Ag & Imrod Pangeran Sinaga & & Edit Del \\
\hline
\end{tabular}

Gambar 6. Tampilan Form Data Alternatif

Proses input alternatif dapat mengklik tombol Add pada sistem sehingga menampilkan form tambah data alternatif yang dapat dilihat pada gambar 7 .

\begin{tabular}{|l|l|}
\hline \multicolumn{2}{|c|}{ Tambah Data Alternatif } \\
\hline ID Alternatif & \\
\hline Nama Alternatif Produk & \\
\hline Deskripsi & \\
\hline & \\
\hline & \\
\hline
\end{tabular}

Gambar 7. Tampilan Form Input Alternatif

Setelah Alternatif diinput, alternatif yang digunakan sebagai calon peneirma BSM divalidasi untuk alternatif yang digunakan dalam metode Moora. Alternatif yang dipilih harus di ceklis pada Form Alternatif. Tampilan dari form alternatif dapat dilihat pada gambar 8 .

\begin{tabular}{|l|l|}
\hline \multicolumn{2}{|c|}{ PILIH ALTERNATIF } \\
\hline$\square$ & Ade Putri Mekaria Laila \\
\hline$\square$ & Juanda Vernis Siahaan \\
\hline$\square$ & Juniver Panca Wibawa \\
\hline$\square$ & Muhammad Reyhan Al Fachizi Lubis \\
\hline$\square$ & Paulus Juninho Manik \\
\hline$\square$ & Rahel Sepetra Sihombing \\
\hline$\square$ & Randika Aditya Bastion Purba \\
\hline$\square$ & Reynardo Sidabutar \\
\hline$\square$ & Samuel Valentino \\
\hline$\square$ & Wisler Siregar \\
\hline$\square$ & Agusto Marpaung \\
\hline$\square$ & Andre Wijaya \\
\hline$\square$ & Angelita Sidauruk \\
\hline$\square$ & Boas Uluan Sibarani \\
\hline$\square$ & Chirta Aulia Sibarani \\
\hline$\square$ & Eldana Marina Hasibuan \\
\hline$\square$ & Hariman Loeis Pramata Bukit \\
\hline$\square$ & Imrod Pangeran Sinaga \\
\hline Proses & \\
\hline & Gambar 8. Tampilan Form Seleksi Alternatif \\
\hline$\square$
\end{tabular}

Gambar 8. Tampilan Form Seleksi Alternatif

4. Nilai alternatif terhadap kriteria

Selanjutnya memberikan nilai alternatif terhadap kriteria pada sistem. Proses input nilai alternatif terhadap kriteria dengan mengklik tombol Add pada sistem sehingga menampilkan form tambah data nilai alternatif terhadap kriteria.

\begin{tabular}{|l|l|}
\hline \multicolumn{2}{|c|}{ Tambah Data Kriteria } \\
\hline Alternatif & \\
\hline Kriteria & \\
\hline Nilai & \multicolumn{2}{|c|}{} \\
\hline & \\
\hline & Simpan \\
\hline
\end{tabular}

Gambar 9. Tampilan Form Tambah Data Kriteria

Setelah input nilai terhadap kriteria yang ditentukan, hasil nilai terhadap kriteria yang telah diinput dapat dilihat pada gambar 10.

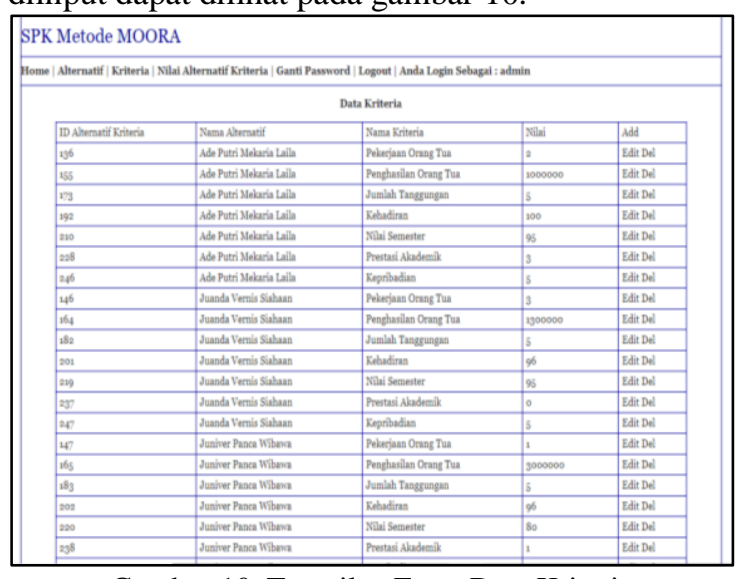

Gambar 10. Tampilan Form Data Kriteria

DOI: $\mathrm{xxxx}$

Lisensi: Creative Commons Attribution 4.0 International (CC BY 4.0) 
Setelah memberikan nilai kriteria pada sistem maka dapat dilihat hasil dari nilai yang diberikan pada sistem. Hasil akhir dari implementasi metode Moora Berbasis Web pada Penentuan Kelayakan Penerima Bantuan Siswa Miskin (BSM) dapat dilihat pada gambar 11 .

\begin{tabular}{|l|l|l|}
\hline Ranking & Alternatif & Nilai Optimasi \\
\hline 1 & Ade Putri Mekaria Laila & 2.2692474858323 \\
\hline 2 & Samuel Valentino & 1.7935789628321 \\
\hline 3 & Muhammad Reyhan Al Fachizi Lubis & 1.7351215962454 \\
\hline 4 & Boas Uluan Sibarani & 1.5580088379735 \\
\hline 5 & Reynardo Sidabutar & 1.5470769075079 \\
\hline 6 & Agusto Marpaung & 1.5321579358789 \\
\hline 7 & Andre Wijaya & 1.521315390715 \\
\hline 8 & Hariman Loeis Pramata Bukit & 1.5141172741491 \\
\hline 9 & Angelita Sidauruk & 1.5097825522683 \\
\hline 10 & Imrod Pangeran Sinaga & 1.487371098868 \\
\hline 11 & Rahel Sepetra Sihombing & 1.4501181283682 \\
\hline 12 & Juanda Vernis Siahaan & 1.4358977509209 \\
\hline 13 & Paulus Juninho Manik & 1.4188074792687 \\
\hline 14 & Randika Aditya Bastion Purba & 1.3986425011778 \\
\hline 15 & Wisler Siregar & 1.3443722493084 \\
\hline 16 & Chirta Aulia Sibarani & 1.2543795886099 \\
\hline 17 & Eldana Marina Hasibuan & 0.91650625465867 \\
\hline 18 & Juniver Panca Wibawa & 0.83408600244566 \\
\hline
\end{tabular}

Gambar 11. Tampilan Hasil Ranking

Berdasarkan gambar 11 dapat dijelaskan bahwa hasil ranking dengan nilai tertinggi diperoleh Ade Putri Mekaria Laila dengan nilai Optimasi 2,22692, tertinggi kedua diperoleh Samuel Valentino dengan nilai Optimasi 1,7935 dan tertinggi ketiga dipeorleh Muhammad Reyhan Al Fahrizi Lubis dengan nilai 1,7351 .

\section{Kesimpulan}

Berdasarkan hasil penelitian dapat dilihat bahwa Ade Putri Mekaria Laila terpilih sebagai alternatif terbaik dengan nilai Optimasi 2,22692. Sehingga dapat disimpulkan Metode Moora merupakan metode yang cocok untuk mendapatkan hasil yang baik di dalam menentukan siswa yang layak menerima bantuan siswa miskin karena dapat mengolah data secara cepat dan tepat sesuai dengan yang diharapkan berdasarkan kriteria kriteria yang telah disajikan.

\section{Referensi}

[1] O. S. Purwaningrum, "Penerapan Metode Fuzzy Tsukamoto Dan Ahp Untuk Sistem Pendukung Keputusan Bantuan Siswa Miskin Pada Smk Muhammadiyah 1 Lamongan," Jurnal Mahasiswa Fakultas Teknik (J-TIIES), vol. 1, no. 1, p. 6, 2017.

[2] F. Fitriani, "The Role of the Education Office in the Formulation of the Implementation of Prevention of Children Prone To Drop Out in the City of Pekanbaru 2013 - 2015," Jurnal Online Mahasiswa Fakultas Ilmu Sosial dan Ilmu Politik Universitas Riau, vol. 5, no. 1, pp. 1-13, 2018.

[3] A. Wanto and E. Kurniawan, "Seleksi Penerimaan Asisten Laboratorium Menggunakan Algoritma AHP Pada AMIKSTIKOM Tunas Bangsa Pematangsiantar," Jurnal Informatika dan Komputer (JIKO), vol. 3, no. 1, pp. 11-18, 2018.

[4] M. Widyasuti, A. Wanto, D. Hartama, and E. Purwanto,
"Rekomendasi Penjualan Aksesoris Handphone Menggunakan Metode Analitycal Hierarchy Process (AHP)," Konferensi Nasional Teknologi Informasi dan Komputer (KOMIK), vol. I, no. 1, pp. 27-32, 2017.

M. Masitha, D. Hartama, and A. Wanto, "Analisa Metode (AHP) pada Pembelian Sepatu Sekolah Berdasarkan Konsumen," Seminar Nasional Sains \& Teknologi Informasi (SENSASI), vol. 1, no. 1, pp. 338-342, 2018.

[6] V. V. Sianipar, A. Wanto, and M. Safii, "Decision Support System for Determination of Village Fund Allocation Using AHP Method," The IJICS (International Journal of Informatics and Computer Science) ISSN, vol. 4, no. 1, pp. 20-28, 2020.

[7] A. P. R. Pinem, H. Indriyawati, and B. A. Pramono, "Sistem Pendukung Keputusan Penentuan Lokasi Industri Berbasis Spasial Menggunakan Metode MOORA," JATISI (Jurnal Teknik Informatika dan Sistem Informasi), vol. 7, no. 3, pp. 639-646, 2020.

[8] N. W. A. Ulandari, N. L. G. P. Suwirmayanti, and N. M. Astiti, "Implementasi Metode MOORA pada Proses Seleksi Beasiswa Bidikmisi di Institut Teknologi dan Bisnis STIKOM Bali," Jurnal Eksplora Informatika, vol. 10, no. 1, pp. 53-58, 2020.

[9] S. B. Rane, P. R. Potdar, and S. Rane, "Data-driven fleet management using MOORA: a perspective of risk management," Journal of Modelling in Management, vol. 16, no. 1, pp. 310-338, 2021.

[10] P. Alkhairi, L. P. Purba, A. Eryzha, A. P. Windarto, and A. Wanto, "The Analysis of the ELECTREE II Algorithm in Determining the Doubts of the Community Doing Business Online," Journal of Physics: Conference Series, vol. 1255, no. 1, pp. 1-7, 2019.

D. R. Sari, N. Rofiqo, D. Hartama, A. P. Windarto, and A. Wanto, "Analysis of the Factors Causing Lazy Students to Study Using the ELECTRE II Algorithm," Journal of Physics: Conference Series, vol. 1255, no. 1, pp. 1-6, 2019. D. M. Sinaga, R. R, R. Alfah, A. P. Windarto, and A. Wanto, "Jurnal Sains dan Informatika," Jurnal Sains dan Informatika, vol. 5, no. 2, pp. 129-135, 2018.

[13] P. P. P. A. N. . F. I. R.H Zer, Masitha, A. P. Windarto, and A. Wanto, "Analysis of the ELECTRE Method on the Selection of Student Creativity Program Proposals," Journal of Physics: Conference Series, vol. 1255, no. 1, pp. 1-6, Aug. 2019.

R. Simarmata, R. W. Sembiring, R. Dewi, A. Wanto, and E. Desiana, "Penentuan Masyarakat Penerima Bantuan Perbaikan Rumah di Kecamatan Siantar Barat Menggunakan Metode ELECTRE," Journal of Computer System and Informatics (JoSYC), vol. 1, no. 2, pp. 68-75, 2020.

S. Sundari, A. Wanto, Saifullah, and I. Gunawan, "Sistem Pendukung Keputusan Dengan Menggunakan Metode Electre Dalam Merekomendasikan Dosen Berprestasi Bidang Ilmu Komputer (Study Kasus di AMIK \& STIKOM Tunas Bangsa)," in Seminar Nasional Multi Disiplin Ilmu, 2017, pp. 1-6.

[16] L. P. Purba, A. P. Windarto, and A. Wanto, "Faktor Terbesar Rendahnya Minat Ber-KB (Keluarga Berencana) dengan Metode ELECTRE II," Seminar Nasional Sains \& Teknologi Informasi (SENSASI), vol. 1, no. 1, pp. 369-374, 2018.

17] S. Sundari, S. M. Sinaga, I. S. Damanik, and A. Wanto, "Sistem Pendukung Keputusan Pemilihan Peserta Olimpiade Matematika SMA Swasta Teladan Pematangsiantar Dengan Metode Electre," in Seminar Nasional Teknologi Komputer \& Sains (SAINTEKS), 2019, pp. 793-799.

S. R. Ningsih, D. Hartama, A. Wanto, I. Parlina, and Solikhun, "Penerapan Sistem Pendukung Keputusan Pada Pemilihan Objek Wisata di Simalungun," in Seminar Nasional Teknologi Komputer \& Sains (SAINTEKS), 2019, pp. 731-735.

DOI: $\mathrm{xxxx}$

Lisensi: Creative Commons Attribution 4.0 International (CC BY 4.0) 
[19] R. N. Sari and R. S. Hayati, "Penerapan Metode Multi [27] Attribute Utility Theory (MAUT) Dalam Pemilihan Rumah Kost," J-SAKTI (Jurnal Sains Komputer dan Informatika), vol. 3, no. 2, pp. 243-251, 2019.

[20] T. Limbong et al., Sistem Pendukung Keputusan: Metode \& Implementasi, 1st ed. Yayasan Kita Menulis, 2020.

[21] K. Fatmawati et al., "Analysis of Promothee II Method in the Selection of the Best Formula for Infants under Three Years," in Journal of Physics: Conference Series, 2019, [29] vol. 1255 , no. 1 , pp. $1-6$.

[22] T. Imandasari, A. Wanto, and A. P. Windarto, "Analisis Pengambilan Keputusan Dalam Menentukan Mahasiswa PKL Menggunakan Metode PROMETHEE," Jurnal Riset Komputer (JURIKOM), vol. 5, no. 3, pp. 234-239, 2018.

[23] S. R. Ningsih, R. Wulansari, D. Hartama, A. P. Windarto, and A. Wanto, "Analysis of PROMETHEE II Method on Selection of Lecturer Community Service Grant Proposals," Journal of Physics: Conference Series, vol. 1255, no. 1, pp. 1-6, Aug. 2019.

[24] R. Watrianthos, W. A. Ritonga, A. Rengganis, A. Wanto, and M. Isa Indrawan, "Implementation of PROMETHEEGAIA Method for Lecturer Performance Evaluation," Journal of Physics: Conference Series, vol. 1933, no. 1, p. 012067, 2021.

[25] R. Panggabean and N. A. Hasibuan, "Penerapan Preference Selection Index (PSI Dalam Sistem Pendukung Keputusan Pengangkatan Supervisor Housekeeping," Rekayasa Teknik Informatika dan Informasi, vol. 1, no. 2, pp. 85-93, 2020.

[26] T. Singh, S. Tejyan, A. Patnaik, R. Chauhan, and G. [33] Fekete, "Optimal design of needlepunched nonwoven fiber reinforced epoxy composites using improved preference selection index approach," Journal of Materials Research and Technology, vol. 9, no. 4, pp. 7583-7591, 2020.
S. Sundari, Karmila, M. N. Fadli, D. Hartama, A. P. Windarto, and A. Wanto, "Decision Support System on Selection of Lecturer Research Grant Proposals using Preferences Selection Index," Journal of Physics: Conference Series, vol. 1255, no. 1, pp. 1-7, 2019.

[28] P. Chen, "Effects of the entropy weight on TOPSIS," Expert Systems with Applications, vol. 168, p. 114186, 2021.

R. A. Hutasoit, S. Solikhun, and A. Wanto, "Analisa Pemilihan Barista dengan Menggunakan Metode TOPSIS (Studi Kasus: Mo Coffee)," KOMIK (Konferensi Nasional Teknologi Informasi dan Komputer), vol. 2, no. 1, pp. 256262, 2018.

[30] N. Nasution, G. W. Bhawika, A. Wanto, N. L. W. S. R. Ginantra, and T. Afriliansyah, "Smart City Recommendations Using the TOPSIS Method," IOP Conference Series: Materials Science and Engineering, vol. 846, no. 1, p. 012028 , May 2020.

[31] T. Imandasari, M. G. Sadewo, A. P. Windarto, A. Wanto, H. O. Lingga Wijaya, and R. Kurniawan, "Analysis of the Selection Factor of Online Transportation in the VIKOR Method in Pematangsiantar City," Journal of Physics: Conference Series, vol. 1255, no. 1, pp. 1-7, 2019.

[32] N. Rofiqo, A. P. Windarto, and A. Wanto, "Penerapan Metode VIKOR Pada Faktor Penyebab Rendahnya Minat Mahasiswa Dalam Menulis Artikel Ilmiah," Seminar Nasional Sains \& Teknologi Informasi (SENSASI), vol. 1, no. 1, pp. 228-237, 2018.

J. Hu, X. Zhang, Y. Yang, Y. Liu, and X. Chen, "New doctors ranking system based on VIKOR method," International Transactions in Operational Research, vol. 27, no. 2, pp. 1236-1261, 2020. 